\title{
Phoretic relationships between Uropodina (Acari: Mesostigmata) and centipedes (Chilopoda) as an example of evolutionary adaptation of mites to temporary microhabitats
}

\author{
JERZY BŁOSZYK ${ }^{1,2}$, JoANnA KLIMCZAK ${ }^{1}$ and MaŁGORZATA LEŚNIEWSKA ${ }^{3}$ \\ ${ }^{1}$ Department of Animal Taxonomy and Ecology, Adam Mickiewicz University, Umultowska 89, 61-614 Poznań, Poland; \\ e-mail: bloszyk@amu.edu.pl \\ ${ }^{2}$ Natural History Collections, Faculty of Biology, Adam Mickiewicz University, Umultowska 89, 61-614 Poznań, Poland \\ ${ }^{3}$ Department of General Zoology, Adam Mickiewicz University, Ulmutowska 89, 61-614 Poznań, Poland
}

Key words. Acari, Mesostigmata, Uropodina, Oodinychus ovalis, Uroobovella pulchella, Chilopoda, Lithobius forficatus, phoresy, Poland

\begin{abstract}
A survey of soil fauna in Poland revealed 30 cases of centipedes carrying mites of the sub-order Uropodina. The 155 phoretic deutonymphs collected belonged to two species of Uropodina - Oodinychus ovalis (C.L. Koch, 1839) and Uroobovella pulchella (Berlese, 1904). These mites displayed a high degree of selectivity in their choice of carrier. The only species of centipede transporting mites was Lithobius forficatus (Linnaeus, 1758), despite the presence of 30 other species in the same habitats. It is possible that the large size and relatively fast speed of movement of this centipede make it a very good mite carrier. The majority of the mites were located on the sides of the centipedes, on segments near the anterior end. The high selectivity in the choice of carrier as well as the point of attachment suggests adaptation by the mites for phoresy by L. forficatus.
\end{abstract}

\section{INTRODUCTION}

Phoresy is a phenomenon involving the active transport of one animal by another. It constitutes a highly effective method of dispersal for small flightless invertebrates, such as mites. It creates an opportunity for them to rapidly colonize temporary microhabitats isolated from one another and spread over a wide area (e.g. tree holes). It is also a strategy for speedy colonization of new areas. Phoretic ability is an essential condition for the survival of species with limited mobility that live in specific microhabitats or temporary environments.

The literature on the subject includes a range of publications concerning links between mites and insects (Faasch, 1967; Ramsey, 1967; Moser, 1976; Desender \& Veneechoutte, 1984; Philips, 1984; Lehtinen, 1987; Athias-Binche \& Habersaat, 1988; Wiśniewski \& Hirschmann, 1992; Athias-Binche, 1993, 1994; Athias-Binche et al., 1993; Mašán, 1993, 1994; Fain et al., 1995; Błoszyk, 1999; Gwiazdowicz, 2000; Błoszyk et al., 2002a; Bajerlein \& Błoszyk, 2004; Bajerlein \& Przewoźny, 2005). There is, however, little information on the dispersal of mites by centipedes. Such information that is available is found in Lewis (1981), who lists 9 species of centipede in which phoresy has been observed. More recently Mašán (2001), in his work on Uropodina in Slovakia, mentions phoretic deutonymphs of Oodinychus ovalis and Uroobovella pulchella on Lithobius forficatus.

The paper reports the links between centipedes and mite species of the sub-order Uropodina*. This group of mites often inhabits decaying or rotten wood and tree holes, creating in this microhabitat a community that is distinct in its species composition from the groups that occur in soil (Błoszyk, 1990; Błoszyk et al., 2003, Markowicz, unpubl. data).

We investigated whether centipedes are being chosen selectively by phoretic deutonymphs, and whether the mites prefer particular parts of the host's body. Bajerlein \& Błoszyk (2004) showed preferences of deutonymphs of $U$. orbicularis towards particular body parts of beetles. We also examined whether the frequency of phoresy depends on anthropogenic modification of the environment.

The results of the research on other mite groups transported by centipedes will be presented in future publications.

\section{MATERIAL AND METHODS}

Material for this study came from research conducted by one of us (Leśniewska) on centipedes in Poland in the years 1995-2004, in 13 habitats at different stages of degradation, from protected areas in natural reserves to urban green areas (Leśniewska, 1999; Leśniewska et al., 2005, Leśniewska, unpubl.).

Centipedes on which mites were found were collected using both qualitative and quantitative methods. The qualitative methods involved seeking out and capture of centipedes in all accessible microhabitats, namely under bark, under moss, from logs and tree trunks, under fallen branches and stones, exposed tree roots, from soil and litter, etc. The quantitative soil-litter samples were collected using a frame with $25 \mathrm{~cm} \times 25 \mathrm{~cm}$ sides, which was inserted into the soil to a depth of about $15-20 \mathrm{~cm}$ depending on habitat conditions. The material collected in this manner was sorted by hand.

Studies were conducted at different times on particular plots. Material collected also varied in the number of samples. The results presented here are preliminary, and the material studied was collected during earlier studies on Chilopoda, which did not focus on the phoresy. Details of where, when and how the samples were collected are shown in Table 1. Localities are described below.

\footnotetext{
* Systematic status correct according to Checklist of Animals of Poland (Wiśniewski, 1997).
} 
TABLE 1. Characteristics of the samples used in the study on phoresy of Uropodina by centipedes.

\begin{tabular}{|c|c|}
\hline Site & Sample type and date of collection \\
\hline 1. Bielinek & litter-soil, quantitative; May $2003\left(1 \mathrm{~m}^{2}\right)$, July $2003\left(2 \mathrm{~m}^{2}\right)$, August $2003\left(2 \mathrm{~m}^{2}\right)$ \\
\hline 2. Cytadela & litter-soil, qualitative; May $2003\left(1 \mathrm{~m}^{2}\right)$, March $2004\left(1 \mathrm{~m}^{2}\right)$, April $2003\left(1 \mathrm{~m}^{2}\right)$, May $2004\left(1 \mathrm{~m}^{2}\right)$ \\
\hline 3. Łopuchówko & $\begin{array}{c}\text { litter-soil, quantitative; November } 2000\left(1 \mathrm{~m}^{2}\right), \text { April } 2001\left(1 \mathrm{~m}^{2}\right) \\
\text { May } 2001\left(1 \mathrm{~m}^{2}\right) \text {, October } 2001\left(1 \mathrm{~m}^{2}\right)\end{array}$ \\
\hline 4. Obrzycko & direct capture; June 2003 \\
\hline $\begin{array}{l}\text { 5. Huby Grzebieniskie } \\
\text { 6. Bytyńskie Brzęki } \\
\text { 7. Brzęki przy Starej Gajówce } \\
\text { 8.-12. Duszniki woodlands }\end{array}$ & $\begin{array}{l}\text { litter-soil, quantitative, total surface area of every sample: } 0,5 \mathrm{~m}^{2} \text {; } \\
\text { each month from May } 2003 \text { to April } 2004\end{array}$ \\
\hline 13. Pieniny National Park & $\begin{array}{c}\text { litter-soil, quantitative and direct capture; July } 1995\left(1 \mathrm{~m}^{2}\right) \text {, September } 1995\left(1 \mathrm{~m}^{2}\right) \text {, } \\
\text { August } 1996\left(1 \mathrm{~m}^{2}\right)\end{array}$ \\
\hline
\end{tabular}

\section{Research sites}

The areas in which cases of phoresy were recorded lie in the northwestern area of Poland, in the Zachodnio-Pomorskie and Wielkopolskie provinces. Phoretic Uropodina were recorded at sites 1-4:

1. Bielinek (BIL). A 75.5 ha nature reserve of forest and grassland in the district of Cedynia (Zachodnio-Pomorskie province), created to preserve areas of mixed forest-grassland on the steep slopes of the Oder valley. There are downy oaks (Quercus pubescens) and numerous xerothermic species from the mediterranean area at this site.

2. Cytadela (CYT). An urban park of approximately 100 ha located in the middle of Poznan. It includes the Winiary military fort established in the 19th century. The wooded and grassy areas are crossed by a network of asphalt and cinder pathways. It is entirely surrounded by a dry moat several meters deep.

3. Łopuchówko (LOP). A 9.28 ha nature reserve, containing oak-pine forest mixed with a sprinkling of hornbeam and beech, comprising part of the Puszcza Zielonka Landscape Park.

4. Obrzycko (OBR). A town located in Wielkopolska district, where the Sama river joins the Warta, to the northwest of Poznań. Centipedes were collected in the 19.2 ha park, which dates from the first half of the 19th century. In this degraded park there are many old, monumental trees (larch, oak, linden).

At sites 5-13, phoretic non-uropodid mites were recorded, or no phoretic mites were recorded (Table 2).

5. Huby Grzebieniskie (HG). A nature reserve of 1.28 ha, created for the protection of oak-hornbeam forest (Galio sylvaticiCarpinetum) and containing the only site of Cypripedium calceolous in the Wielkopolska district.

6. Bytyńskie Brzęki (BB). A nature reserve of 14.24 ha in the Wielkopolska district, oak hornbeam forest with a large number of Sorbus torminalis.

7. Brzęki przy Starej Gajówce (BG). A nature reserve in Wielkopolska of $5.96 \mathrm{ha}-\mathrm{a}$ fragment of hornbeam forest with one of the highest concentrations of Sorbus torminalis in Wielkopolska.

8-12. Duszniki woodlands. The next 5 areas are in the Wielkopolska district. The area of the whole forest complex amounts to $0.9 \mathrm{~km}^{2}$. The first two areas (G1 and G2) are located in an old stand of trees (over 120 years old). The third area (G3) is an approximately 60 -year-old oak-hornbeam forest that has grown up on a site that was clear-falled. The next two areas (G4 and G5) are approximately 20-year-old clear-falled sites on which oak saplings were planted immediately after felling.

13. Pieniny National Park (PNP). The study area of 2.5 ha was established in the beech forest Fagetum carpaticum in the Pieniński Potok Valley.

\section{Characteristics of phoretic mites and their hosts}

Uroobovella pulchella (Figs 1-6). A European species occurring in Poland evenly across the entire country. It is associated mainly with rotten tree stumps as well as decomposing logs and tree holes, where it achieves its highest frequency and is only sporadically encountered in soil. It is particularly associated with spruce and fir forests as well as with stands of pine. It is a lowland species with optimal occurrence below $500 \mathrm{~m}$ above sea level. It reproduces parthenogenically, though in particular populations males may occur sporadically (sex ratio $1: 100$ ) (Błoszyk, 1999). U. pulchella is a phoretically transported species. In the investigated material a total of 56 phoretic deutonymphs were found, all transported by L. forficatus.

Oodinychus ovalis (Figs 7-11). A common, widely occurring European species, found in many countries. It occurs evenly across the entire area of Poland. It prefers the soil and litter of various types of forest, but a significant part of its population also inhabits unstable microhabitats (merocenoses) and open environments. The optimal occurrence of the species is generally accepted to be below $500 \mathrm{~m}$ above sea level, but it has also been found at an altitude of $1300 \mathrm{~m}$. O. ovalis is an abundant species phoretically transported by centipedes. A total of 99 phoretic deutonymphs were observed being transported by centipedes.

Lithobius forficatus (Chilopoda, Lithobiomorpha). A eurytopic, West-Palearctic species. It is the most common centipede in Poland, inhabiting the whole area of the country, in all types of habitat - forests, meadows, grasslands, peatbogs and wastelands, both at sealevel and to $2000 \mathrm{~m}$ a.s.l. L. forficatus is common in all synanthropic habitats. It is the biggest representative of Lithobiomorpha in Poland. Due to its large size (up to 35 $\mathrm{mm}$ long) it is especially abundant where there are stumps, rotten logs, branches, boards and stones on the ground - under which it finds shelter (Kaczmarek, 1979, 1980; Leśniewska, 1996, 1997).

\section{RESULTS}

Phoretic mites belonging to several systematic groups were recorded on 141 individuals $(6.9 \%)$ out of the total of 2018 specimens of 31 species of Chilopoda that were collected (Table 2). Phoretic mites were found on 10 different species of Chilopoda, but Uropodina were found only on one species. They were associated exclusively with Lithobius forficatus. Deutonymphs were recorded on 30 individuals of this centipede, which was $1.5 \%$ of all captured Chilopoda and $21.3 \%$ of the mite-carrying centipedes. Mites of the sub-order Uropodina constituted 33.4\% of all the mites recorded on centipedes. A total of 155 phoretic deutonymphs of the sub-order Uropodina were collected, belonging to two species of mite - Uroobovella pulchella and 


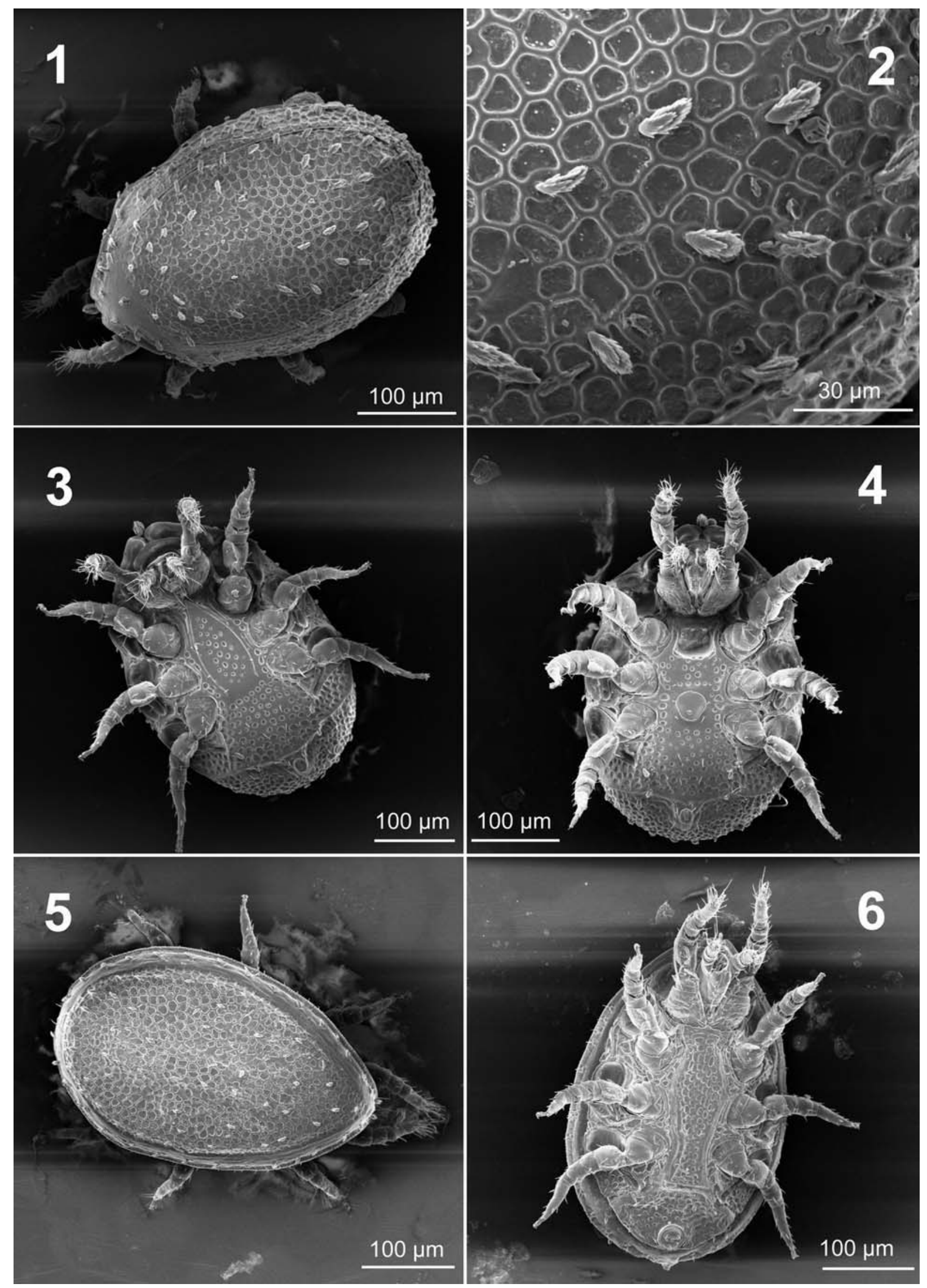

Figs 1-6. Uroobovella pulchella - species transported by Lithobius forficatus: 1 - female, dorsal side, 2 - sculpture and dorsal chaetotaxy, 3 - female, ventral side, 4 - male, ventral side, 5 - phoretic deutonymph, dorsal side, 6 - phoretic deutonymph, ventral side. 


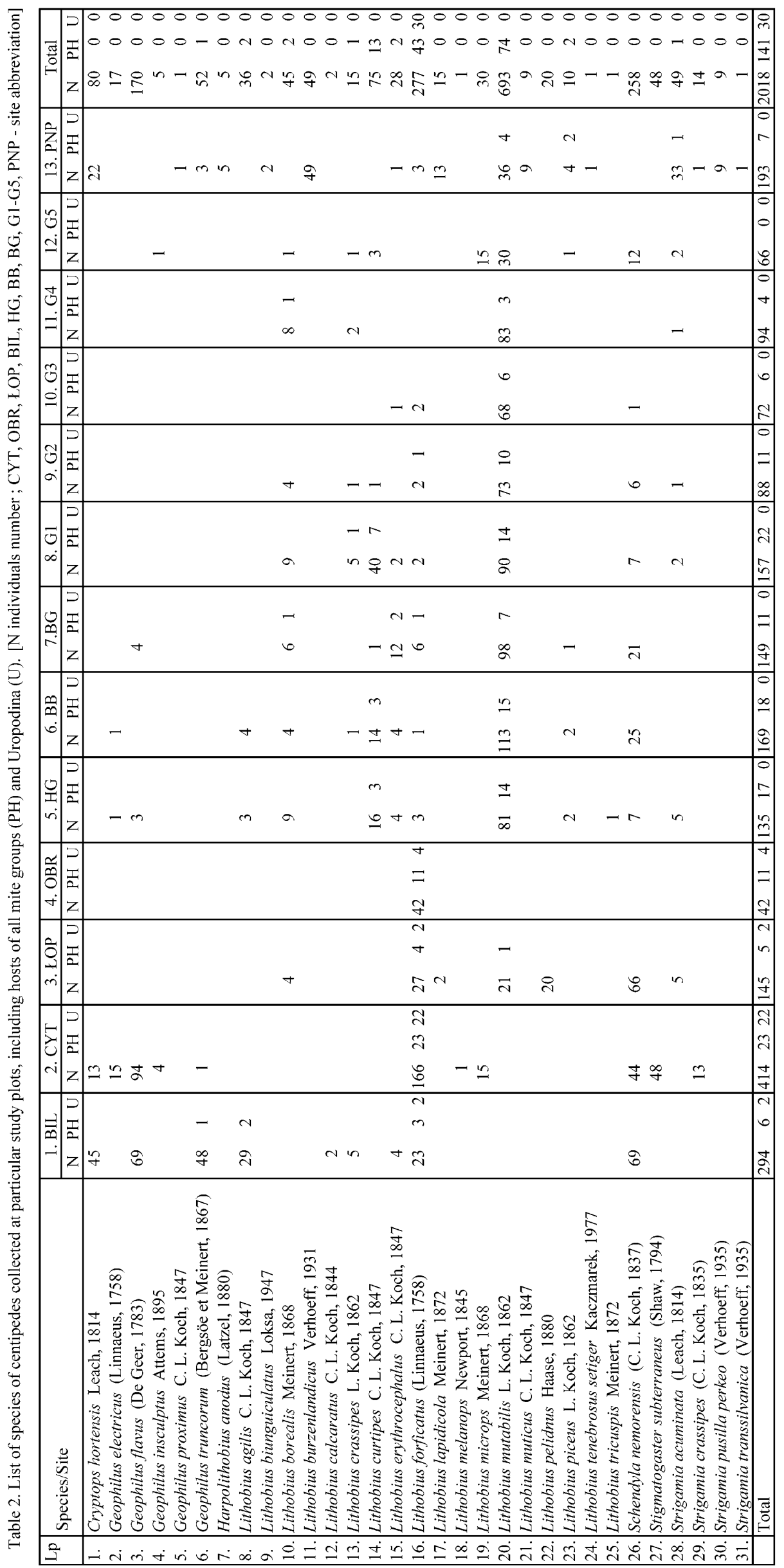



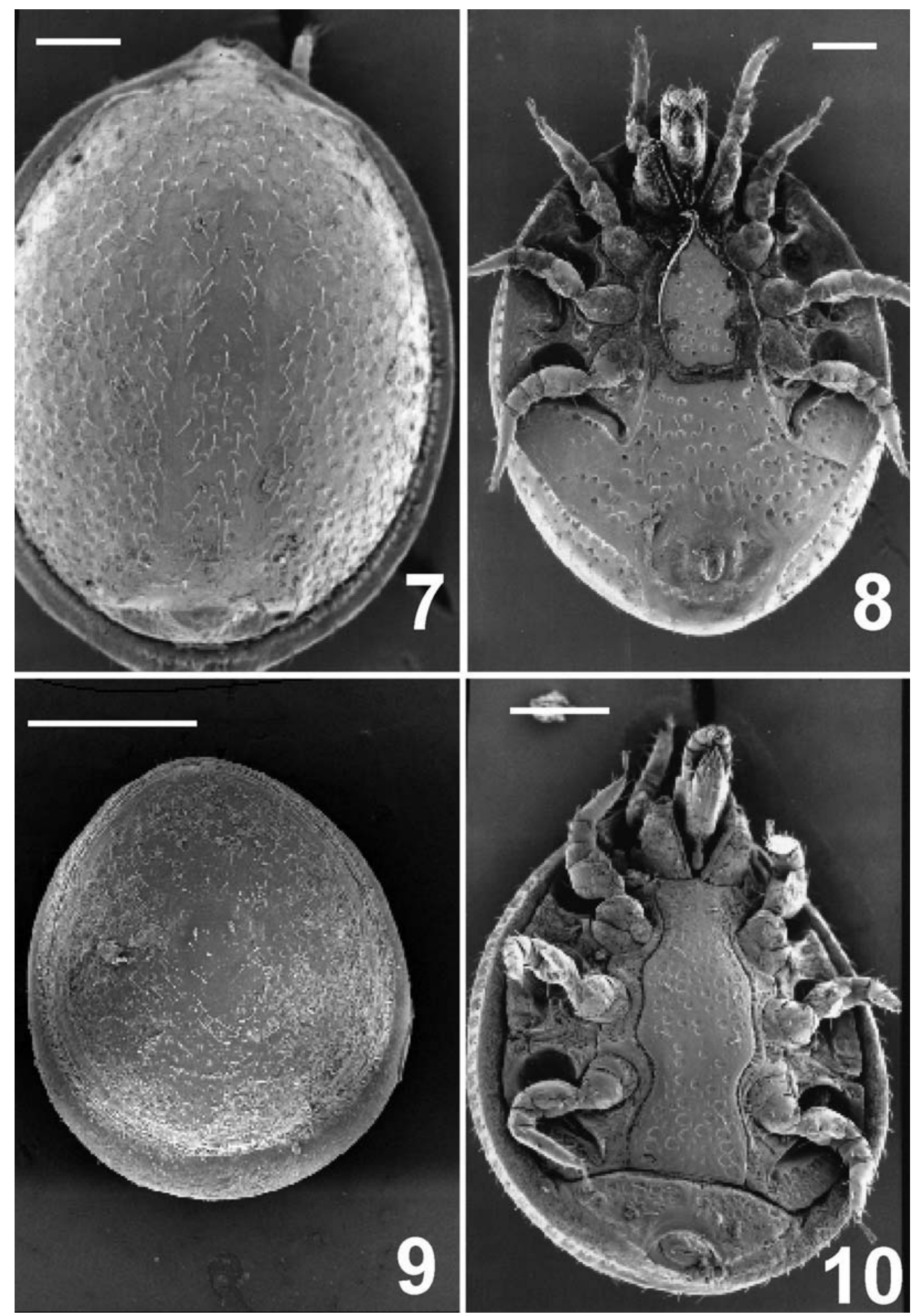

Figs 7-10. Oodinychus ovalis - species transported by Lithobius forficatus: 7 - female, dorsal side, 8 - female, ventral side, 9 phoretic deutonymph, back, 10 - phoretic deutonymph, ventral side.

Oodinychus ovalis (Tables 3, 4). The other mite groups represented were Pygmephoridae and Histiostomatidae.

In almost all cases $(97 \%)$ the centipede transported only one species of mite. Only one centipede was recorded transporting both species of Uropodina.

\section{Mite preference for particular centipede body segments}

Mites of the sub-order Uropodina were most frequently attached to the sides of a centipede ( $99 \%$ of mites) (Fig. 11).
Only one $U$. pulchella phoretic deutonymph was found on the dorsal surface of a centipede. There were, however, no cases in which mites attached themselves to the ventral side of a centipede.

We confirmed that Uropodina occurred on all segments of centipedes, apart from the head, the forcipular segment and the small $\mathrm{XV}^{\text {th }}$ segment. Most phoretic deutonymphs were attached close to the head - on the third (14.5\%), fifth (12.5\%) and sev- 


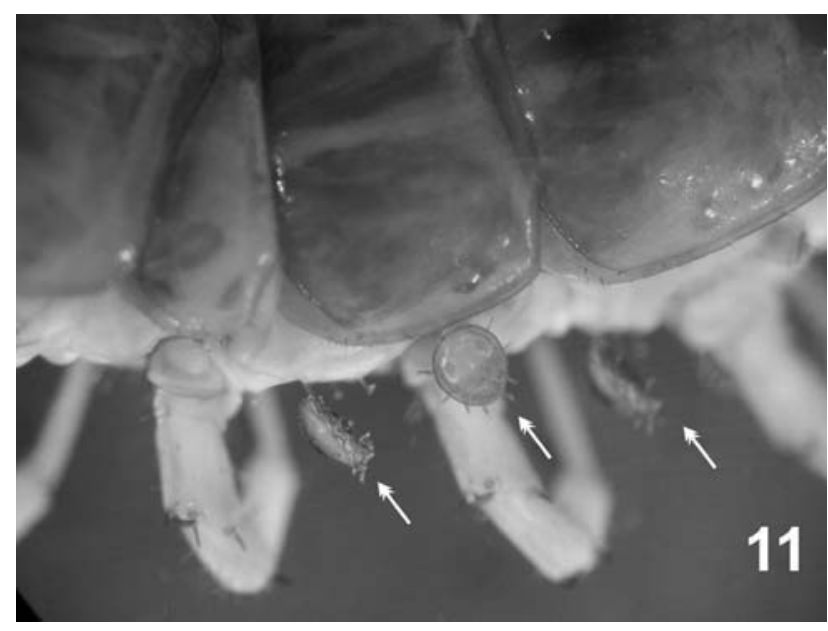

Fig.11. Oodinychus ovalis - deutonymphs transported by Lithobius forficatus.

enth $(10.6 \%)$ segments. The greatest percentage of $U$. pulchella phoretic deutonymphs, however, were on the second segment of L. forficatus. Attachment to the thirteenth segment was relatively rare $(1.4 \%)$, as was attachment to the ninth and eleventh $(2.0 \%)$ and sixth segments $(2.1 \%)$ (Table 3$)$. Preference for anterior segments of the body of $L$. forficatus was marked in $U$. pulchella and less so in $O$. ovalis.

The mites usually occurred singly on individual parts of a centipede's body. Less frequently two (18.6\%) or three (10.3\%) individuals were found on the same segment. Cases of four $(4.1 \%)$ or even six phoretic deutonymphs $(1.0 \%)$ on a single segment of a centipede were very infrequent.

\section{Location of habitats where phoresy occurs}

Centipedes transporting mites were found in both natural and anthropogenic habitats. Of the 11 sites located in various parts

TABLE 3. Presence of mites on specific centipede segments (\%).

\begin{tabular}{cccc}
\hline $\begin{array}{c}\text { Body segment } \\
\text { L. forficatus }\end{array}$ & U. pulchella & O. ovalis & $\begin{array}{c}\text { Uropodina } \\
\text { total }\end{array}$ \\
\hline Head & 0 & 0 & 0 \\
Forcipular & 0 & 0 & 0 \\
I & 10.7 & 5.2 & 7.3 \\
II & 21.4 & 2.1 & 9.3 \\
III & 12.5 & 15.6 & 14.5 \\
IV & 7.1 & 4.2 & 4.7 \\
V & 14.3 & 11.5 & 12.5 \\
VI & 3.6 & 1.1 & 2.1 \\
VII & 7.1 & 12.5 & 10.6 \\
VIII & 1.8 & 11.5 & 7.9 \\
IX & 3.6 & 1.1 & 2.0 \\
X & 8.9 & 8.3 & 8.6 \\
XI & 0 & 3.1 & 2.0 \\
XII & 8.9 & 7.3 & 7.9 \\
XIII & 0 & 2.1 & 1.4 \\
XIV & 0 & 7.3 & 4.7 \\
XV & 0 & 0 & 0 \\
Intermediate & 0 & 7.3 & 4.7 \\
\hline Total & 100 & 100 & 100 \\
\hline
\end{tabular}

of Wielkopolska, as well as in 2 located in other parts of Poland, from which the centipedes came, phoretic Uropodina were found at only 4 . The incidence of individuals of $L$. forficatus carrying Uropodid mites at particular sites was: in the Cytadela park, Poznan $-13.25 \%$, the Obrzycko park $-9.5 \%$, the Bielinek reserve $-8.7 \%$, and the Łopuchówko reserve $-7.41 \%$.

\section{DISCUSSION}

Unlike the nonspecific phoresy of Uropoda orbicularis Müller, 1776 by coprophilous beetles of several families (Bajerlein \& Błoszyk, 2004; Bajerlein \& Przewoźny, 2005) as well as other groups of insects, both species of Uropodina found in the present study selected a particular carrier. It is significant that the mites of the sub-order Uropodina recorded in this study were transported by a single species of centipede - Lithobius forficatus, despite the fact that this species coexists with 30 other species of centipede. This raises the question how these mite select their carrier. This is particularly so for Oodinychus ovalis, which is not so selective with regard to insects. It has been recorded on 13 species of beetles, belonging to several different families (Carabidae, Silphidae, Scaphidiidae, Elateridae, Cucujidae, Erotylidae, Endomychidae, Scarabaeidae and Anthribidae). The majority of these beetles are associated with dead wood. It is also found on many other species of beetle, such as Cychrus rostratus, Agonum sp., Silpha sp., Scaphidium quadrimaculatum, Elater sanguineus, Cucujus cinnaberinus, Triplax aenea, Endomychus coccineus, Geotrupes stercorosus, Valgus hemipterus, Dorcus parallelopipedus and Anthribius sp. (Mašán, 2001).

Unlike the mites living in extremely temporary and dispersed microhabitat such as cattle dung, those species associated with dead wood in forests only have to traverse short distances. We suggest that the genesis of the relationships between Uropodina and centipedes developed as follows. In the prevailing climatic conditions in Central Europe the climax plant community is normally forest. Originally the majority of the land was covered with trees. Mites, moving from one rotting stump to another, did not have to cross large distances. In this case, it was not necessary dispersed by winged insects, which are able to cover significant distances. They used therefore as a carrier a large species of centipede, occurring in large numbers in this environment, able to cover easily the distance separating one merocenosis from another. This predator is very mobile and can move rapidly from one place to another, especially at night. During the day L. forficatus remains motionless, hidden in dead wood or under bark. At that time it is easy for the relatively slow-moving phoretic deutonymphs to attach themselves to a carrier. In attaching themselves to the sides of the body close to the coxa mites are less likely to be damaged during transport. Mites do not attach themselves to the underside or dorsum of centipedes, where they would be quickly dislodged when centipedes squeeze through narrow cracks in wood. It cannot be entirely discounted, though, that some mites attach themselves to the tergites or sternites of centipedes, but become dislodged.

The greater intensity of phoresy in anthropogenic environments, such as parks, may be explained by the greater distance between the microhabitats inhabited by mites. In parks trees are more sparsely distribute and there is less dead wood on the ground, thus mites have to tranverse greater distances. Furthermore, the chances of finding an appropriate habitat by a phoretic deutonymph is smaller in parks than in forest. It seems, therefore, justified to accept the hypothesis that the natural biological reaction of mites in such a situation is increased phoresy. This adaptation would account for the observations reported here.

The existence of the phoretic link between $O$. ovalis and $L$. forficatus testifies to a long-association between these two 
TABLE 4. Location of mites on individual specimens of Lithobius forficatus (Lf-L. forficatus, Up - U. pulchella, Oo - O. ovalis, $\mathrm{D}$ - dorsal, L - lateral, ? - unidentified location - mite dislodged, $I$ - intermediate segment).

\begin{tabular}{|c|c|c|c|c|c|c|c|c|c|c|c|c|c|c|c|c|c|c|c|c|}
\hline \multirow[b]{2}{*}{ No. } & \multirow[b]{2}{*}{ Site } & \multirow{2}{*}{$\begin{array}{l}\text { Sex } \\
L f\end{array}$} & \multirow{2}{*}{$\begin{array}{c}\text { Mite } \\
\text { species }\end{array}$} & \multicolumn{16}{|c|}{ Mite location on segments } & \multirow{2}{*}{$\begin{array}{c}\text { Total number of } \\
\text { mites } \\
\text { on the centipede }\end{array}$} \\
\hline & & & & I & II & III & IV & $\mathrm{V}$ & VI & VII & VIII & IX & $\mathrm{X}$ & XI & XII & XIII & XIV & $I$ & $?$ & \\
\hline 1. & Bielinek & t & $U p$ & $\begin{array}{l}1 \\
\mathrm{~L}\end{array}$ & $\begin{array}{l}2 \\
\mathrm{~L}\end{array}$ & $\begin{array}{l}1 \\
\mathrm{~L}\end{array}$ & & & & & & & & & & & & & & 4 \\
\hline 2. & Bielinek & o & $U p$ & $\begin{array}{l}1 \\
\mathrm{~L} \\
\end{array}$ & $\begin{array}{l}2 \\
\mathrm{~L} \\
\end{array}$ & $\begin{array}{l}1 \\
\mathrm{~L} \\
\end{array}$ & $\begin{array}{l}1 \\
\mathrm{~L} \\
\end{array}$ & & $\begin{array}{l}1 \\
\mathrm{~L} \\
\end{array}$ & & & & & & & & & & & 6 \\
\hline 3. & Cytadela & q & $U p$ & $\begin{array}{l}1 \\
\mathrm{~L}\end{array}$ & $\begin{array}{l}2 \\
\mathrm{~L}\end{array}$ & $\begin{array}{l}1 \\
\mathrm{~L}\end{array}$ & $\begin{array}{l}1 \\
\mathrm{~L}\end{array}$ & $\begin{array}{l}3 \\
\mathrm{~L}\end{array}$ & & $\begin{array}{l}1 \\
\mathrm{~L}\end{array}$ & & & $\begin{array}{l}1 \\
\mathrm{~L}\end{array}$ & & & & & & & 10 \\
\hline 4. & Cytadela & q & $U p$ & $\begin{array}{l}1 \\
\mathrm{~L}\end{array}$ & & $\begin{array}{l}1 \\
\mathrm{~L}\end{array}$ & & & & & & & & & & & & & & 2 \\
\hline 5. & Cytadela & q & $U p$ & & & & & $\begin{array}{l}1 \\
\mathrm{~L}\end{array}$ & & $\begin{array}{l}1 \\
\mathrm{~L}\end{array}$ & & & $\begin{array}{l}1 \\
\mathrm{~L}\end{array}$ & & & & & & & 3 \\
\hline 6. & Cytadela & q & Up, Oo & & $\begin{array}{l}1 \\
\mathrm{~L}\end{array}$ & & & $\begin{array}{l}4 \\
\mathrm{~L}\end{array}$ & & & $\begin{array}{l}2 \\
\mathrm{~L}\end{array}$ & & $\begin{array}{l}1 \\
\mathrm{~L}\end{array}$ & & & & $\begin{array}{l}2 \\
\mathrm{~L}\end{array}$ & $\begin{array}{l}3 \\
\mathrm{~L}\end{array}$ & & 13 \\
\hline 7. & Cytadela & q & Oo & $\begin{array}{l}1 \\
\mathrm{~L} \\
\end{array}$ & & $\begin{array}{l}2 \\
\mathrm{~L} \\
\end{array}$ & & $\begin{array}{l}3 \\
\mathrm{~L} \\
\end{array}$ & & $\begin{array}{l}2 \\
\mathrm{~L} \\
\end{array}$ & $\begin{array}{l}2 \\
\mathrm{~L} \\
\end{array}$ & & & $\begin{array}{l}3 \\
\mathrm{~L} \\
\end{array}$ & & & $\begin{array}{l}3 \\
\mathrm{~L} \\
\end{array}$ & & & 16 \\
\hline 8 & Cytadela & q & Oo & & & & & & & & & $\begin{array}{l}1 \\
\mathrm{~L} \\
\end{array}$ & $\begin{array}{l}1 \\
\mathrm{~L} \\
\end{array}$ & & $\begin{array}{l}1 \\
\mathrm{~L} \\
\end{array}$ & & & & & 3 \\
\hline 9. & Cytadela & 운 & Oo & & & & & & & & & & & & $\begin{array}{l}1 \\
\mathrm{~L}\end{array}$ & & & & & 1 \\
\hline 10. & Cytadela & & Oo & & & $\begin{array}{l}1 \\
\mathrm{~L}\end{array}$ & & & & & $\begin{array}{l}1 \\
\mathrm{~L}\end{array}$ & & & & & & & & & 2 \\
\hline 11. & Cytadela & q & Oo & & & & $\begin{array}{l}1 \\
\mathrm{~L}\end{array}$ & & & & & & $\begin{array}{l}1 \\
\mathrm{~L}\end{array}$ & & & & & & & 2 \\
\hline 12. & Cytadela & q & Oo & & & $\begin{array}{l}3 \\
\mathrm{~L}\end{array}$ & $\begin{array}{l}1 \\
\mathrm{~L}\end{array}$ & & & $\begin{array}{l}3 \\
\mathrm{~L}\end{array}$ & $\begin{array}{l}1 \\
\mathrm{~L}\end{array}$ & & $\begin{array}{l}1 \\
\mathrm{~L}\end{array}$ & & & $\begin{array}{l}1 \\
\mathrm{~L}\end{array}$ & & $\begin{array}{l}4 \\
\mathrm{~L}\end{array}$ & & 14 \\
\hline 13. & Cytadela & q & Oo & & $\begin{array}{l}2 \\
\mathrm{~L}\end{array}$ & & & $\begin{array}{l}2 \\
\mathrm{~L}\end{array}$ & & $\begin{array}{l}2 \\
\mathrm{~L}\end{array}$ & $\begin{array}{l}2 \\
\mathrm{~L}\end{array}$ & & & & $\begin{array}{l}1 \\
\mathrm{~L}\end{array}$ & & $\begin{array}{l}1 \\
\mathrm{~L} \\
\end{array}$ & & & 10 \\
\hline 14. & Cytadela & q & Oo & & & & & & & & & & & & & $\begin{array}{l}1 \\
\mathrm{~L} \\
\end{array}$ & & & & 1 \\
\hline 15. & Cytadela & q & Oo & & & & & & & & & & $\begin{array}{l}1 \\
\mathrm{~L}\end{array}$ & & & & & & & 1 \\
\hline 16. & Cytadela & & Oo & & & $\begin{array}{l}3 \\
\mathrm{~L}\end{array}$ & & & & & & & $\begin{array}{l}1 \\
\mathrm{~L}\end{array}$ & & $\begin{array}{l}1 \\
\mathrm{~L}\end{array}$ & & & & & 5 \\
\hline 17. & Cytadela & q & Oo & & & & $\begin{array}{l}1 \\
\mathrm{~L}\end{array}$ & & & & & & & & $\begin{array}{l}1 \\
\mathrm{~L}\end{array}$ & & & & & 2 \\
\hline 18. & Cytadela & q & Oo & & & & $\begin{array}{l}1 \\
\mathrm{~L}\end{array}$ & $\begin{array}{l}1 \\
\mathrm{~L} \\
\end{array}$ & & & & & & & & & & & & 2 \\
\hline 19. & Cytadela & $\sigma$ & Oo & & & & & & & & & & $\begin{array}{l}1 \\
\mathrm{~L}\end{array}$ & & & & & & & 1 \\
\hline 20. & Cytadela & o & Oo & $\begin{array}{l}1 \\
\mathrm{~L}\end{array}$ & & & & & & & & & & & & & & & & 1 \\
\hline 21. & Cytadela & 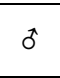 & Oo & & & $\begin{array}{l}6 \\
\mathrm{~L}\end{array}$ & & $\begin{array}{l}1 \\
\mathrm{~L}\end{array}$ & & $\begin{array}{l}4 \\
\mathrm{~L} \\
\end{array}$ & $\begin{array}{l}2 \\
\mathrm{~L}\end{array}$ & & & & $\begin{array}{l}1 \\
\mathrm{~L}\end{array}$ & & $\begin{array}{l}1 \\
\mathrm{~L}\end{array}$ & & & 15 \\
\hline 22 & Cytadela & $\delta$ & Oo & & & & & & $\begin{array}{l}1 \\
\mathrm{~L}\end{array}$ & & & & & & & & & & & 1 \\
\hline 23. & Cytadela & t & Oo & & & & & & & & & & & & & & & & $\begin{array}{l}1 \\
?\end{array}$ & 1 \\
\hline 24. & Cytadela & $\sigma$ & Oo & & & & & & & $\begin{array}{l}1 \\
\mathrm{~L}\end{array}$ & $\begin{array}{l}1 \\
\mathrm{~L} \\
\end{array}$ & & $\begin{array}{l}1 \\
\mathrm{~L} \\
\end{array}$ & & & & & & & 3 \\
\hline 25. & Łopuchówko & q & Oo & $\begin{array}{l}4 \\
\mathrm{~L} \\
\end{array}$ & & & & & & & & & & & & & & & & 4 \\
\hline 26. & Łopuchówko & 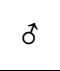 & Oo & & & & & & & & & & $\begin{array}{l}1 \\
\mathrm{~L}\end{array}$ & & $\begin{array}{l}1 \\
\mathrm{~L}\end{array}$ & & & & & 2 \\
\hline 27. & Obrzycko & 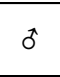 & $U p$ & $\begin{array}{l}1 \\
\mathrm{~L}\end{array}$ & $\begin{array}{l}1 \\
\mathrm{~L}\end{array}$ & $\begin{array}{l}2 \\
\mathrm{~L}\end{array}$ & & $\begin{array}{l}2 \\
\mathrm{~L}\end{array}$ & & & & & $\begin{array}{l}2 \\
\mathrm{~L}\end{array}$ & & $\begin{array}{l}2 \\
\mathrm{~L}\end{array}$ & & & & & 10 \\
\hline 28. & Obrzycko & o & $U p$ & & $\begin{array}{l}3 \\
\mathrm{~L} \\
\end{array}$ & $\begin{array}{l}1 \\
\mathrm{~L}\end{array}$ & $\begin{array}{l}1 \\
\mathrm{D}\end{array}$ & $\begin{array}{l}2 \\
\mathrm{~L}\end{array}$ & & & & $\begin{array}{l}1 \\
\mathrm{~L}\end{array}$ & & & & & & & & 8 \\
\hline 29. & Obrzycko & t & $U p$ & & & & $\begin{array}{l}1 \\
\mathrm{~L}\end{array}$ & $\begin{array}{l}1 \\
\mathrm{~L}\end{array}$ & $\begin{array}{l}1 \\
\mathrm{~L}\end{array}$ & & & & & & & & & & & 3 \\
\hline 30. & Obrzycko & o & $U p$ & $\begin{array}{l}1 \\
\mathrm{~L}\end{array}$ & $\begin{array}{l}1 \\
\mathrm{~L}\end{array}$ & $\begin{array}{l}1 \\
\mathrm{~L}\end{array}$ & & $\begin{array}{l}1 \\
\mathrm{~L}\end{array}$ & & $\begin{array}{l}2 \\
\mathrm{~L}\end{array}$ & $\begin{array}{l}1 \\
\mathrm{~L}\end{array}$ & $\begin{array}{l}1 \\
\mathrm{~L}\end{array}$ & $\begin{array}{l}1 \\
\mathrm{~L}\end{array}$ & & & & & & & 9 \\
\hline \multicolumn{4}{|c|}{ TOTAL } & 12 & 14 & 23 & 8 & 21 & 3 & 16 & 12 & 3 & 14 & 3 & 9 & 2 & 7 & 7 & 1 & 155 \\
\hline
\end{tabular}


organisms. The evolution of specific phoretic adaptations and selectivity with regard to the carrier indicate that originally this species of mite was associated with dead wood. Perhaps the transfer to life in the soil occurred later, possibly as a direct result of the loss of phoretic deutonymphs in forest litter.

It is possible that the method of sampling also influenced the frequency of phoresy recorded in the different study plots. Phoretic Uropodina were not found in samples collected in the oakhornbeam forests of Wielkopolska (HG, BB, BG, G1-G5). Centipedes were captured only from litter-soil samples. Thus, only a low number of $L$. forficatus, which is found mainly in stumps and rotten logs, was collected. None of the individuals carried mites, despite the presence of both phoretic Uropodid species in the litter and rotten wood (Błoszyk et al., 2003). This would indicate that the frequency of phoresy is lower in forests than in parks. It is interesting that $L$. forficatus was the only centipede recorded with Uropodina - for unknown reasons phoresy was not recorded on other species.

The abundance of $O$. ovalis in the soil in Wielkopolska is relatively low and very variable, as previous studies have shown. The abundance of these mites in individual plots varied from 1 to 137 individuals per $1 \mathrm{~m}^{2}$, with the lowest in the reserves and highest in forests and parks influenced by human activity. The abundance of $U$. pulchella depends on the amount of rotten wood present in the area (Błoszyk et al., 2002b, c, 2003). The qualitative and quantitative structure of centipede communities and its influence on Uropodid mite phoresy during the season will be the subject of further studies.

For insects with large numbers of mites attached to their body (sometimes in excess of 100 individuals), phoresy can be harmful, as they prevent the insect from flying, inhibit movements and may even result in exhaustion and death (Bajerlein \& Błoszyk, 2004). In such cases we are dealing with transport parasitism. The centipedes observed in this study normally carried from 1 to a maximum of 16 phoretic uropodine deutonymphs, which is not a great burden for the host. Lewis (1981) also emphasises that the phoretic relationship is not parasitic for centipedes as the mites do not harm them.

ACKNOWLEDGEMENTS. This study was funded by grants sponsored by KBN funds (No. 2 PO4G 12228 and 2 PO4G 061 29). The authors wish to thank B. Halliday (CSIRO, Canberra, Australia) for help in preparing the manuscript, and the reviewers of the paper for valuable comments and suggestions.

\section{REFERENCES}

Athias-Binche F. 1993: Dispersal in varying environments: the case at phoretic uropodid mites. Can. J. Zool. 71: 1793-1798.

Athias-Binche F. 1994: La Phoresie chez les Acariens. Aspects Adaptatifs et Évolutifs. Editions du Castillet, Perpignan, 178 pp.

Athias-Binche F. \& Habersatit U. 1988: An ecological study of Janetiella pyriformis (Berlese, 1920), a phoretic Uropodina from decomposing organic matter (Acari: Anactinotrichida). Mitt. Schweiz. Entomol. Ges. 61: 377-390.

Athias-Binche F., Schwarz H.H., Meierhofer I. 1993: Phoretic association of Neoseius novus (Ouds., 1992) (Acari: Uropodina) with Necrophorus spp. (Coleoptera: Silphidae): a case of sympatric speciation? Intern. J. Acarol. 19: 75-86.

Bajerlein D. \& BŁoszyK J. 2004: Phoresy of Uropoda orbicularis (Acari: Mesostigmata) by beetles (Coleoptera) associated with cattle dung in Poland. Eur. J. Entomol. 101: 185-188.

BAJERLEIN D. \& PrZewoźNY M. 2005: Coprophagous hydrophilid beetles (Coleoptera: Hydrophilidae) as carriers of phoretic phoretic deutonymphs of Uropoda orbicularis (Acari: Mesostigmata) in Poland. Eur. J. Entomol. 102: 119-122.
BŁoszyK J. 1990: Fauna of Uropodina mites (Acari: Mesostigmata) of decayed tree stumps and hollows in Poland. Zeszyty Probl. Postęó́w Nauk Roln. (Warszawa) No. 373: 217-235.

BŁoszyK J. 1999: Geograficzne i ekologiczne zróżnicowanie zgrupowań roztoczy z kohorty Uropodina (Acari: Mesostigmata) w Polsce. I. Uropodina lasów gradowych (Carpinion betuli). [Geographical and ecological variability of mites of the kohort Uropodina (Acari: Mesostigmata) in Poland. I. Uropodine mites of oak-hornbeam forests (Carpinion betuli).] Kontekst, Poznań, 245 pp. [in Polish].

BŁoszyk J., Bajerlein D. \& BŁaszak C. 2002a: The use of pedicels of phoretic deutonymph of Uropoda orbicularis (Acari: Uropodidae) connected with coprophagus beetles (Insecta: Coleoptera) by Macrocheles female mites (Acari: Macrochelidae) in the process of dispersion. Pol. Pismo Entomol. 71: 241-246.

Błoszyk J., Krysiak D., Napierala A. \& Bajaczyk R. 2002b: Materiały do znajomości Uropodina (Acari: Mesostigmata) wybranych rezerwatów położonych na obszarze parków krajobrazowych województwa wielkopolskiego. [The materials to knowledge of Uropodina (Acari: Mesostigmata) of selected natural reserves in the area of landscape parks of Wielkopolska.] Bul. Park. Krajobarz. Wielkopol. 8(10): 62-72 [in Polish].

BŁoszyk J., Krysiak D., Napierąa A. \& Markowicz M. 2002c: Ocena stanu środowiska glebowego wybranych rezerwatów leśnych województwa wielkopolskiego w oparciu o zgrupowania roztoczy z podrzędu Uropodina (Acari: Mesostigmata). [W:] 1. [The evaluation of soil enviroment of selected forest natural reserves of Wielkopolska district based on communities of mites from suborder Uropodina (Acari: Mesostigmata).] In: Ochrona przyrody. Raport o stanie środowiska $w$ Wielkopolsce $w$ roku 2001. [Enviroment Protection. Report about the State of Natural Enviroment in Wielkopolska in 2001.] Biblioteka Monitoringu Środowiska, pp. 21-31 [in Polish].

BŁoszyk J., Napierata A. \& Markowicz-Rucińska M. 2003: Zróżnicowanie zgrupowań Uropodina (Acari: Mesostigamata) wybranych rezerwatów Wielkopolski. [Variability of uropodid mites communities (Acari: Mesostigmata) in some natural reserves in Wielkopolska.] Parki Nar. Rez. Przyr. 22: 285-298 [in Polish].

Desender K. \& Veneechoutte M. 1984: Phoretic associations of carabid beetles (Coleoptera: Carabidae) and mites (Acari). Rev. Ecol. Biol. Sol. 21: 363-371.

FAASCH H.H. 1967: Beitrag zur Biologie der einheimischen Uropodiden Uroobovella marginata (C.L. Koch 1839) und Uropoda orbicularis (O.F Müller 1776) und experimentelle Analyse ihres Phoresieverhaltens. Zool. Jb. Syst. 94: 521-608.

Fain A., Noti M.I. \& Dufrene M. 1995: Observation on the mites (Acari) associated with Carabidae (Coleoptera) in Belgium. I. Annotated list of the species. Intern. J. Acarol. 21: 107-122.

GwiAzDOwCZ D.J. 2000: Mites (Acari, Gamasida) associated with insects in the Białowieża National Park. Acta Parasitol. 45: 43-47.

Kaczmarek J. 1979: Pareczniki (Chilopoda) Polski. Ser. Zool. 9. Wydawnictwo Naukowe UAM, Poznań, 99 pp.

Kaczmarek J. 1980: Pareczniki (Chilopoda). Katalog Fauny Polski. 14, 4. PWN, Warszawa, 43 pp.

LEHTINEN P.T. 1987: Association of uropodid, polyaspidid, antennophorid, sejid, microgynid, and zerconid mites with ants. Entomol. Tidskr. 108: 13-20.

LeŚNIEwSKa M. 1996: Centipedes of Poznań town (Poland). In Geoffroy J.-J., Mauriès J.-P. \& Nguyen Duy-Jacquemin M. 
(eds): Acta Myriapodologica. Mém. Mus. Natn. Hist. Nat. 169: 221-224.

LeŚNIEWSKA M. 1997: Zgrupowanie pareczników (Chilopoda) w rezerwacie przyrody "Buki nad jeziorem Lutomskim". [Chilopoda Community in the Natural Reserve "Buki nad jeziorem Lutomskim".] Ser. Zool. 23. Wydawnictwo Naukowe UAM, Poznań, 83 pp. [in Polish].

LeŚniewsKa M. 1999: Centipedes (Chilopoda) of the Pieniński Potok Valley (the Pieniny National Park). Rocz. Nauk. Pol. Tow. Ochr. Przyr. "Salamandra" 3: 67-74.

Leśniewska M., Koralewska-Batura E. \& BŁoszyk J. 2005 Centipede communities in oak-hornbeam forests of different ages and exploitation in Wielkopolska (Poland). Peckiana 4: 69-79.

LewIS J.G.E. 1981: The Biology of Centipedes. Cambridge University Press, Cambridge, 476 pp.

MAŠÁn P. 1993: Mites (Acarina) associated with Trox (Coleoptera: Scarabaeidae). Eur. J. Entomol. 90: 359-364.
MAšÁn P. 1994: The mesostigmatic mites (Acarina, Mesostigmata) associated with the dung beetles in South Slovakia. Biologia 49: 201-205.

MAšÁn P. 2001: Mites of the cohort Uropodina (Acarina, Mesostigmata) in Slovakia. Ann. Zool. Botan. 223: 1-320.

Moser J.C. 1976: Phoretic carrying capacity of flying southern pine beetles (Coleoptera: Scolytidae). Can. Entomol. 108: 807-808.

PhILIPS J. 1984: Acarine symbionts of trogid beetles. Acarology 6: $552-556$.

Ramsey G.W. 1967: Phoretic mites associated with insects. N. Z. Entomol. 3: 6-7.

WIŚNIEWSKI J. 1997: Uropodina. In Razowski J. (ed.): Checklist of Animals of Poland. Vol. 4. Polska Akademia Nauk, Wroclaw-Warszawa-Kraków, pp. 202-205.

WIŚNIEWSKI J. \& HIRSCHMANN W. 1992: Phoretic deutonymphs of three new Uroobovella species from the USA (Dinychini, Uropodiae). Intern. J. Acarol. 18: 43-48.

Received November 24, 2005; revised and accepted January 3, 2006 